\title{
Desire, Dispossession, and Dreams of Social Data: Black Clubwomen's Intellectual Thought and Aesthetics During the Progressive Era in Public Writing and Print Culture
}

\section{Erica Richardson}

Carefully and conscientiously we shall study the questions, which affect the race most deeply and directly. Against the convict lease system, the Jim Crow car laws, lynchings and all other barbarities which degrade us, we shall protest with such force of logic and intensity of the soul that those who oppress us will either cease to disavow the inalienability and equality of human rights, or be ashamed to openly violate the very principles upon which this government was founded.

-Mary Church Terrell, "What Role is the Educated Negro Woman to Play" (1902)1

The immorality of colored women is a theme upon which those who know little about them or those who maliciously misrepresent them love to descant. Foul aspersions upon the character of colored women are assiduously circulated by the press of certain sections and especially by the direct descendants of those who in years past were responsible for the moral degradation of their female slaves [...] Dotted all over the country are charitable institutions for the aged, orphaned, and poor which have been established by colored women, just how many it is 
difficult to state, owing to the lack of statistics bearing on the progress, possessions, and prowess of colored women.

-Mary Church Terrell, "The Progress of Colored Women" $(1904)^{2}$

In the late nineteenth and early twentieth centuries, black middle-class women around the United States formed a series of clubs to mobilize a racial uplift reform movement. They created kindergartens and reading groups. ${ }^{3}$ They encouraged and guided the cultivation of black homes. And above all else, black clubwomen, as they came to be known, worked tirelessly to address the myriad challenges the black race faced with the rollback of civil rights following the end of Reconstruction and the steady rise of racial prejudice and antiblack violence. ${ }^{4}$ By way of introduction into this essay's focus on the archive of black clubwomen's public writing and print culture, I offer a reading of the two passages above by Mary Church Terrell. Terrell was one of the most influential and powerful black women's club leaders and the first president of the national network of black clubwomen, the National Association of Colored Women (NACW). In the first selection above, taken from a speech delivered to a meeting of black clubwomen, "What Role is the Educated Negro Woman to Play," Terrell draws on a series of issues related to the social realities for black Americans. The convict lease system practically undermined the Thirteenth Amendment abolishing slavery, the Jim Crow train cars vacated the Fourteenth Amendment ensuring equal rights to blacks as citizens, and lynchings negated perhaps all of the Reconstruction amendments, threatening black death in response to any semblance of black life and equality, from voting rights to the sheer attempt at black dignity.

Terrell illustrates the social and political awareness of black clubwomen, but it is her carefully crafted sentimental tone that captures my attention for it indicates an ability to refashion epistemological tools to assert black women's authority and agency. For example, when Terrell proclaims black clubwomen's potential to intervene "with such force of logic and intensity of the soul," she aligns reason with spirituality, effectively combining two categories of thought and knowledge production typically regarded as mutually exclusive during the period. ${ }^{5}$ Victorian middle-class women were given province over the home, emotions, and care of the family, but rarely were they perceived as mobilizing a set of politics based on their intellectual abilities. Black women were often excluded from this cultural standard due to race. Terrell combines logic and the soul to assert black women's ability to meet a middle-class standard and to give them greater authority to perceive, think, and reimagine black social and political life not only for the benefit of blacks but also for the substantiation of "the inalienability and equality of human rights." And yet, as the second selection suggests, that was not enough to persuade American society to recognize what black clubwomen knew of their work and themselves.

In Terrell's later speech "The Progress of Colored Women," published in the black periodical the Voice of the Negro, full recognition of black women's 
citizenship and social progress within American society is elusive because black women are paradoxically unknown and yet overdetermined social subjects. The insistence upon black female immorality erases the progress of black women from slavery to the present. As Terrell notes, the dissemination of false claims about black women occurs because of the circulation of uninformed and biased opinion in the press, and, critically, the absence of social statistics that might demonstrate the great strides black women had made in their communities.

My reading of these passages from Terrell's work presents in brief what I propose is a larger discursive event that occurs across black clubwomen's writing. Within the archive of their public writing and print culture from the 1890s through 1910s, black clubwomen sought to prove to American society that they were ideal American citizens and that their lives were worthy of social interest. However, their convictions were rarely substantiated by American society. They strove to employ a range of epistemological tools, including different rhetorics, sentimental style, and what was often elusive yet desired during the period, social data regarding the lives of black women. Ultimately black clubwomen's use of these epistemological tools cultivated their intellectual thought and produced a set of aesthetics across their archive. This framing of their archive and interdisciplinary theory of their discourse has the potential to expand our scholarly understanding of ideological sites of contestation related to black social life at the turn of the century, including the "Negro problem," dispossession, and experience, while offering a more capacious approach to reading and interpreting black women's early literary production.

While the social and political importance of black clubwomen's work is readily acknowledged (especially by black women historians of the 1980s and 1990s), the intertwined intellectual and aesthetic implications of their writing are often under discussed. ${ }^{6}$ This occurs for a few reasons. In their efforts to create "better homes" among the masses, black clubwomen expressed a class bias against working-class women. ${ }^{7}$ Scholars importantly critique this aspect of black clubwomen's rhetoric and reform, but in the process fail to consider what else their writing could be doing. And black women were doing a lot of writing at the turn of the century. As Hazel Carby observes, there was a flourishing of black women's writing in the late nineteenth and early twentieth centuries, which led to the time period being referred to as "the Woman's Era" amongst black intellectuals and authors, in recognition of the prolific work and writing of black women. ${ }^{8}$ But often, as Elizabeth McHenry explains, the work of women during this period is regarded by contemporary scholars as lacking the "literary skills" to warrant literary interpretation. ${ }^{9}$ These challenges altogether dissuade scholars from focusing on the robust yet fragmented archive of black clubwomen's writing. ${ }^{10}$ In her text Beyond Respectability: The Intellectual Thought of Race Women, Brittney Cooper critiques such limitations and calls for a scholarly engagement that is constituted by more than a "recovery imperative" of simple acknowledgment and respect. Instead, she asks scholars to "trust" black women intellectuals: "By trust, I don't mean always agree. I mean acknowledge, appreciate, struggle 
with, disagree with, sit with, and question. I mean take Black women seriously" (original emphasis). ${ }^{11}$ I take Cooper's formulation of trust here as a critical praxis of black feminism that has the capacity to expand on black intellectual history, as Cooper indicates, and to establish the writing of clubwomen more squarely within literary history and periodical studies. As I index and examine black clubwomen's public writing and print culture, I trust that the choices they make in their writing are deliberate, with a specific set of intended intellectual and aesthetic consequences.

Using a praxis of black feminism predicated on trust to close read the writing of black clubwomen, I examine a series of selections from the archive of black clubwomen's public writing and print culture. After first exploring how the writing of black clubwomen engages the history and ideology of the Progressive Era, particularly in respect to the ideological term and trope of the "Negro problem," I analyze a seminal speech by Fannie Barrier Williams at the 1893 World's Exposition in Chicago, which was written primarily for a white audience; and two pieces, an editorial profile and a sketch, from The Woman's Era (1894-1897), the first periodical written by and for black women. In these selections black clubwomen use an intermedial style of composition, attuned to the historical and ideological terrain of the Progressive Era (e.g. the rhetoric of evidence, data, and social facts) to simultaneously critique the denigration of black women and create alternative uplifting narratives and representations of black women. ${ }^{12}$

\section{Shaping the Nation: The "Negro Problem," and Social Data during the Progressive Era}

During the Progressive Era, evidentiary theories of social progress amidst the vast social changes of modernity shaped how Americans perceived themselves and the nation. This in turn would advance the stakes of both the so-called "Negro problem" and the production and use of social data (e.g. reports, facts, and statistics) about black life. Starting in the 1880s, blacks were migrating in increasing numbers from the South to the North or to cities, seeking industrial jobs in cities and an escape from the overt anti-black violence in the South. ${ }^{13}$ The incorporation of blacks along with European immigrants into American society and the nation necessarily brought forth questions about the progress of society and what it meant to be an American, potentially destabilizing the ideologies of American identity based on the logics of exclusivity and the primacy of the white American man. The project of assimilation for black Americans - shaped by the legacies of slavery, the failure of Reconstruction, and the consolidation of white supremacy through the establishment of Jim Crow-was not simply an appeal but also a reckoning with the so-called "Negro problem."

The "Negro problem" is an ambiguous trope that indexes a number of discourses and ideologies at the turn of the twentieth century. Taken up by black leaders and intellectuals, it could highlight the injustices black Americans faced, 
especially under the Jim Crow regime. Taken up by white supremacists, it could surmise black political ineptness or inability to improve upon their transition from slavery. Ultimately, the trope itself did not predicate one specific argument about the future of the black race but instead pronounced entry into debate about the futurity of black social and political life. The contestation within this trope was further defined by sociology and reform movements of the Progressive Era that were respectively invested in solving social "problems," which could be specific to a social group or the result of modern change. Craig Calhoun explains, "Progress was a fundamental theme for the emerging field of sociology and the broader social context of its reception [...] In the United States, the problem of order became to a large extent the problem of integration - how to assimilate immigrants, how to overcome (or at least deal with) racial division, and how to nurture self-improvement and strong families among the poor." 14 The circulation of sociological conceptualizations of the "Negro problem" also emerged on account of an increase in studies about black Americans corresponding with a rise in the culture of social facts and popular interest in social data that tracked the shifts of modernity. ${ }^{15}$

Still, the use of social data, much like the "Negro problem" itself, did not guarantee an objective truth or narrative of progress. On the one hand social data could be used to shore up white supremacy and pronounce the pathology of black social life. From journalistic social reports published in popular magazines to lynching statistics published in newspapers, the most commonly circulated and institutionalized social data gathered about black people served to consolidate black pathology. White reformer Eleanor Tayleur, in her article "Social and Moral Decadence" (1904) in Outlook magazine, integrated stereotypes of black women drawn from the legacies of slavery and social Darwinism in a brief social history of black women, in order to present them as sexually pathological within modern society:

As she exists in the South today [the black woman] is the Frankenstein product of civilization, a being created out of conditions or sectional hate and revenge, and set in motion by wild experimentalists.[...]Shut out by her blood from the privileges of white womanhood and by her sex from the opportunities of the negro men, she is the victim of every injustice of society, and she revenges herself upon it by striking at the very foundations of political and social structure. She has always been a hapless sacrifice to the lust of man, and retribution has made her a Nemesis who has forged the thunderbolts of the race question for the white man and who stands a sinister figure behind the black man, forever dragging him downward. ${ }^{16}$

Tayleur finds the black woman to be a product of her social conditions and history, which in turn makes the black woman substantially detrimental to 
American society's social and political structure on account of her dispossession and corresponding sexual frailty. Even as Tayleur accounts for conditions and history, she still presents the black woman as the ultimate pathological subject due to the black woman's harbored resentment and hypersexuality, creating racial conflict for white men and dragging black men down. This article became a popular touchstone for discussing black women as social subjects and was reprinted in the New York Tribune in 1904.

On the other hand, black intellectuals could use social data as an epistemological tool to excavate the pathologies of prejudice within white society. Several contemporaries of black clubwomen accomplished such work, including, notably, Ida B. Wells, Kelly Miller, and W.E.B. Du Bois. Their respective engagement with social data to shape public perception helps define the scale and stakes of such information for black clubwomen as well. Wells was in fact a clubwoman, but often was pushed to the periphery of clubs and organizations due to her strident yet compelling antilynching campaign. ${ }^{17}$ In her groundbreaking antilynching pamphlets, Wells used journalistic research and lynching statistics from a white mainstream newspaper, the Chicago Tribune, to effectively debunk the false claim that black men around the nation were lynched because they raped white women. ${ }^{18}$ In Southern Horrors: Lynch Law in All Its Phases, she transforms the statistics from a list of black criminality and death into a count of the white women desiring black men, and she supplies journalistic reports of such romances at length. In A Red Record, Tabulated Statistics and Alleged Causes of Lynching in the United States, 1892-1893-1894 she exposes the breadth of antiblack violence as it is inflicted on men but also children and women around the country, highlighting how antiblack violence rarely discriminates in regard to gender or age, and that the race as a whole is threatened by lynching for the crime of blackness. Indeed, as my overview suggests, Wells's work exemplifies how social data can depict black social life otherwise - revelations that might compel a change in public opinion and, equally as important, a shift in black collective subjectivity. With her refashioning of statistics, she creates a different affective space for black collective subjectivity: where there was once shame and there can now be mourning, where there was dishonor, righteous rage. ${ }^{19}$ These are the shifts that Wells expresses in her rhetoric on behalf of black men. At the same time, she does not and cannot have an extended focus on social data about black women themselves because of the precarity of switching focus from black men to the violence committed against black women (which is why I offer limited focus on Wells in the context of black clubwomen's desire for social data about black women).

Early black sociologists like W.E.B. Du Bois and Kelly Miller sought to shape the social theory and facts surrounding the "Negro problem" by critiquing racist social studies or conducting their own surveys on black populations. They both, for example, contended with the work of white statistician Frederick Hoffman. In his 1896 work Race Traits and Tendencies of the Negro, Hoffman argued that based on statistical "evidence," the black race was biologically ill equipped 
to survive. He was hired by an insurance company to gather evidence to justify higher premiums for black people, but his work would ultimately gain broader institutional authority as it was further sponsored by the prestigious American Economic Association. In the text, Hoffman compiles 300 pages of tables and figures from censuses, public health bureaus, and military reports. ${ }^{20}$ After his first series of data illustrating the death rate for the Negro as twice that of the white man, he reaches the following conclusion that "the vitality of the negro may well be considered the most important phase of the so-called race problem; for it is a fact...that of all races for which statistics are obtainable, and which enter at all into consideration of economic problems as factors, the negro shows the least power of resistance in the struggle for life." ${ }^{21}$ With such empirical evidence of black pathology and failure to thrive, how could the black race be expected to assimilate into society and the nation? Such condemnations prompted a series of black intellectuals to respond to the racist use of social data. In his review of Race Traits, black sociologist Kelly Miller insists that "[freedom] from conscious personal bias does not relieve the author from the imputation of partiality to his own opinions beyond the warrant of the facts which he has presented. Indeed, it would seem that his conclusion was reached from a priori considerations and that the facts have been collected in order to justify it. ${ }^{22} \mathrm{Du}$ Bois himself criticized Hoffman on the grounds of egregious statistical manipulations and errors. ${ }^{23}$ In his response, Du Bois declares, "Most of the conclusions drawn from [Hoffman's] facts are, however, of doubtful value, on account of the character of the material, the extent of the field, and the unscientific use of the statistical method." 24 In other words, not only did Hoffman use the data to substantiate a popular prejudiced sentiment about the race, but his work was also unscientific. ${ }^{25}$

While this discussion focuses on how black clubwomen use social data, it is also critical to note that they performed sociological studies and developed social theory in their reform work and writing. Their position in the history of sociology, unlike Miller and Du Bois, however, has gone largely unnoticed except for a select few feminist sociologists, who have recognized black clubwomen's seminal work and contributions. Francille Rusan Wilson, in The Segregated Scholars: Black Social Scientists and the Creation of Black Labor Studies, 1890-1950, observes that the first national organization of black clubwomen, the NACW, routinely sought to promote reform work based on scientific empiricism. Mary Jo Deegan, Patricia Madoo Lengermann, and Jill Niebrugge-Brantley similarly note that women in the social sciences, including black clubwomen, were incredibly active during the Progressive Era, creating empirical and humanist approaches to cultivating social data and developing social theory. ${ }^{26}$ Historically black clubwomen are excluded from histories of social science because they did not engage with - or rather were not given access to - the educational institutions and academic journals. Practically speaking, beyond black clubwomen's own local surveys, there was a dearth of information about black women as social subjects. Consequently, black clubwomen often used data from either their own local surveys or aggregated surveys or already-published statistics in order to 
figure out which black homes were prospering and which ones needed the guidance and support, whether through financial support or through lessons in "home training," much like the settlement work of Jane Addams at Hull House. ${ }^{27}$

The limited social data black clubwomen possessed often required radical reframing to express what black women knew to be the truth of their own lives. Even with the task of revision and reframing though, there still remained the issue of presenting black women as having a social history and a distinct intellectual and political bearing on American society. Because American society primarily produced prejudiced accounts of black women's social lives, black women were deprived of social history or social data authentic to their own experience. Black clubwoman Fannie Barrier Williams takes up this issue of dispossession in particular in her speech "The Intellectual Progress of the Colored Women," contemplating both the loss engendered by slavery and the contemporary lack of recognition or social data about black women's striving and successes in spite of slavery. In the process she reveals how social interest is best understood as a prelude to social data itself and begins to creatively imagine how that data could lead to a better potential artistic representation of black women in American literature and art.

\section{Fannie Barrier Williams and an Aesthetic Theory of Dispossession and Artistic Production}

In her 1893 speech "The Intellectual Progress of the Colored Women of the United States Since the Emancipation Proclamation," Fannie Barrier Williams explains that dispossession and creative representation of black women are related. According to Williams, because the social history and social facts about the lives of black women from slavery to the present are unknown in American society, the artistic representation, narratives, and even characterization of black women are deficient if not harmful. Her lament about the lack of social data, however, does not end in a solicitation for pity. Instead, it extends into an aesthetic theory. Williams looks at the failure of black representation and the limits of the American imaginary and compares these losses with the striving of black clubwomen. The truth about black women as experienced and demonstrated by black clubwomen, should be rendered into social data, which she postulates will compel American society to produce a new, better art regarding black women. She forms this theory in her speech, which she notably delivered to the Women's Congress, a smaller conference held primarily by white clubwomen at the 1893 World's Columbian Exposition in Chicago. ${ }^{28}$

As Lee Baker observes, the Chicago Exposition emphasized "hard science, high art, and exacting technology evidenced in the progress of American civilization and the progress of the civilized mind." 29 The exhibitions demonstrated the refined social thought of white society and defined other black and brown peoples and their nations as belonging to a fascinating yet inferior culture. The Women's Congress consisted primarily of white women and initially opposed 
the participation of black women. The Women's Congress only allowed a select few black women, including Williams, to participate, after they protested and Williams appealed to a U.S. Congressman. ${ }^{30}$ Williams's audience at the Chicago Exhibition was reluctant at best, yet she was determined to impress upon her listeners that black women had a unique social history worthy of social study and documentation and, indeed, artistic attention.

At the beginning of her speech, Williams pronounces that her talk is focused on black women's "intellectual progress" and laments the lack of interest in black women's social history which she presents as a loss for black women themselves, and, importantly, for American society. Wary of critiquing her audience outright, she crafts an appeal by theorizing from a subject position of dispossession-but not in the way one initially may assume. Instead of framing dispossession as the total subsuming experience of black women from slavery to the present, she focuses on what American society has to lose by ignoring black women:

There has been no special interest in their peculiar condition as native-born American women. Their power to affect the social life of America, whether for good or ill, has excited not even speculative interest. Though there is much that is sorrowful, much that is wonderfully heroic, and much that is romantic in a way in their history, none of it has been told as evidence of what is possible for these women. How few of the happy, prosperous, and eager living Americans can appreciate what it all means to be suddenly changed from irresponsible bondage to the responsibility of freedom and citizenship! ${ }^{31}$

For Williams dispossession can be a resource instead of simply tainting or overshadowing black women. Dispossession is not an event relegated to the past but a sense of loss that can be owned, wielded, and compelling. It can satisfy the aesthetic sensibilities of Americans in the present with "much that is romantic" and "sorrowful" and "wonderfully heroic." Because "none of it has been told as evidence," dispossession is ironically and obviously burgeoning with possibility-for after so much loss there can only be gains in Williams's estimation. To be sure, slavery has an afterlife, but it does not subsume the agency, subjectivity, and potentiality of black women. Slavery and its legacies might qualify the modern black woman as a social subject, but it does not define her. With this understanding of dispossession Williams can also solicit the enfranchisement of black women with her allusions to the fact that black women, as the descendants of slaves, are "native-born" and positioned to enact civic duty or "[t]heir power to affect the social life of American society." Ultimately, Williams advises her audience to imagine and interpret the dispossession of black women as the unknown that will inspire art, and as central to a form of citizenship that should be substantiated. ${ }^{32}$ 
Still, for the aesthetic and political implications that Williams imagines to emerge, there must be social interest in black women, who are, as she explains, distinctly ignored:

First it should be noticed that the separate facts and figures relative to colored women are not easily obtainable. Among the white women of the country, independence, progressive intelligence, and definite interests have done so much that nearly every fact and item illustrative of their progress and status is classified and easily accessible. Our women, on the contrary, have had no advantage of interests peculiar and distinct and separable from those of men that have yet excited public attention and kindly recognition. ${ }^{33}$

American society documents and contemplates the "woman question" as it relates to white women and the condition of black life as it relates to black men who excite "public attention and kindly recognition." Williams's critique calls for a prototypical intersectionality that might augment the desire for social data on black women. She makes this critique with the assertion that if the public is interested in the progress of white women and black men, then surely, there is a place for black women in the American social imagination. Williams continues to attribute special aesthetic potential to the work of black clubwomen in spite of the current lack of social interest. She anticipates that the progress of black women as inspiration for the American artistic imagination capable of improving the whole American society still fragmented by the effects of the Civil War and Reconstruction. She implies as much by juxtaposing the dearth of representation in the arts with the wealth of black clubwomen's reform work:

In less than another generation, American literature, American art, and American music will be enriched with productions having new and peculiar features of interest and excellence. The exceptional career of our women will yet stamp itself indelibly upon the thought of this country. American literature needs for its greater variety and deeper soundings that which will be written into it out of the hearts of these self-emancipating women. The great problems of social reform that are now so engaging the highest intelligence of American women will soon need for their solution in the reinforcement of that new intelligence which our women are developing. In short, our women are ambitious to be contributors to all the great moral and intellectual forces that make for the great weal of our common country. ${ }^{34}$

Williams imagines an era of artistic representation where the work of black women and their strivings will be inspirational for art. Indeed, perhaps she heralds 
the already burgeoning literary production by black women like Frances Harper or Pauline Hopkins that occurs in 1890 and continues through the $1900 \mathrm{~s} .{ }^{35}$ She envisions broader artistic representation inspired by "self-emancipating women" and a corresponding "intellectual force" that can heal divides of the country caused by the Civil War or the "great weal of our common country." It is notable here that Williams is careful never to assume that her appeal is for the benefit of black women alone. In the speech at length, she lists the number of accomplishments black clubwomen have made in facilitating "home training" for working-class black women, gaining education, and leading church culture away from superstition, all the while practicing rationalism and sympathy so that it becomes clear that "the power of organized womanhood is one of the most interesting studies of modern sociology." ${ }^{36}$ As she lists these achievements, she is careful to highlight the benefit of black clubwomen's reform and intellectual work for themselves and the rest of America, hoping that her emphasis on the reform work might lead to better social data in the general public about the lives of black women. At the same time, Williams maintains that cultivating such accounts of black women would be for mutual benefit of black women and American society. This could be regarded as pronouncing black women's embeddedness in American society and nation, ensuring that when black women gain access and opportunity, others will immediately benefit as well (e.g. Anna Julia Cooper's formulation of "when and where I enter"). ${ }^{37}$ Alternatively, this insistence on mutuality also undermines the racial component of her intersectional critique, especially in regards to the depiction - or lack thereof - of white American culpability in the history of slavery.

In her appeal to the white woman audience of the Women's Congress, Williams evades a definitive accusation of the culpability of white America within black women's social transition from slave to would-be citizen. In her claim that many Americans would enjoy the story of the change "from irresponsible bondage to the responsibility of freedom and citizenship!" she erases white agency within the institution of slavery and the failed project of Reconstruction. The effect is disconcerting as she refuses to explicitly pronounce the ethical reality that the oppressed cannot be responsible for their condition. Forgoing the acerbity of direct condemnation may well be worthwhile though if white women can become a sympathetic audience to the black woman. Williams seemingly makes this concession to white fragility so that black clubwomen could gain recognition for their progress and citizenship. And such concessions, importantly, undergird a more unwieldy sense of white anxiety about the progress and the potentiality of black women - how they might be the ideal citizens even when black women by virtue of race and gender should be the furthest from a modern imagination of nation in America. More than a palliative for the unsettling process of assimilation or racial tensions, social facts and data and a corresponding artistic production might vividly substantiate how black women practically embody the ideals of the nation in their historical striving and contemporary intellectual thought. In "The Intellectual Progress of the Colored Women" Williams solicits white America for social interest and offers a substantial aesthetic theory that 
revises a political imaginary of America. Her theory occurs in part because of the absence of social data and in part because of her majority white audience. The expression of a more experimental set of aesthetics less centered on placating and pleasing white sensibilities emerges, however, when black clubwomen write for an explicit audience of black women readers in the black clubwoman periodical, The Woman's Era.

\section{"We Cannot Know Too Much": The Woman's Era and Writing for an Audience of Black Women}

What happens when black women write to and for themselves? What does it mean for them to know themselves through one another? What can emerge when they adjust from lamenting their illegibility in American society and start to see one another as the authoritative intellectuals and the audience that they were always looking for? This is the shift in intent that occurs in the space of The Woman's Era, the first black periodical written by black women and explicitly for an audience of black women. Their desire for social data in the periodical evolves, enabling a series of aesthetic expressions. In the first example under discussion, an editorial profile, the aesthetic expression includes the presentation of an admirable black female persona and the rhetorical generation of affective collectivity. Recalling Terrell's concern about the white press's denigration of black women and Eleanor Tayleur's conviction that black women would bring down both white and black men, we can appreciate what it meant for black women to look to mainstream print culture and see how it circulated false social facts, narratives, and characterizations of themselves. Black clubwomen had to engage, to intervene, or the white press would continue to unmake them as social subjects and pose pathological figures in their stead. Aesthetic expression also occurs in The Woman's Era because of its features and conventions as a modern black periodical, as well as its associations with the NACW.

Clubwomen Josephine Ruffin and her daughter Florida Ridley edited The Woman's Era. It disseminated black clubwomen's discourse and was central to the early formation of the NACW. ${ }^{38}$ Although Ruffin maintained editorial control of the periodical as she published it in Boston, she sought to produce a national black women's audience by including contributions from black clubwomen writers from around the country, including Victoria Earle Matthews (New York), Fannie Barrier Williams (Chicago), Josephine Silone-Yates (Kansas City), Mary Church Terrell (Washington, D.C.), Elizabeth Ensley (Denver), and Alice Ruth Moore (New Orleans). While The Woman's Era's objectives and interests were specific to black clubwomen (e.g. black middle-class and educated black women), it fits within a tradition of modern periodical culture, featuring the use of interdisciplinary discourse and evolving composition practices. ${ }^{39}$ The Woman's Era's incorporation of sociology and social thought into the broader spectrum of black women's accounts of club activities, black culture, and social life anticipates Harlem Renaissance magazines like Crisis, Messenger, and Opportunity, which 
enabled white and black social scientists to read and write about critical issues in African American culture and life with the activist purpose of undermining racist stereotypes. ${ }^{40}$ Its standard columns changed every few months, with the exceptions of "The Literature Department" by Medora Gould, notes on the social happenings of different clubs, and Ruffin's own editorials. The overall composition of The Woman's Era often was malleable to the point of being mercurial, including an array of editorials, profiles, reports, cultural reviews, short stories, sketches, and poems. The periodical's search for an ideal composition may have been part of a search for an "educational ideal," or the best way of teaching the public. ${ }^{41}$ At the same time, the lack of consistency in composition also enabled the periodical's intermediality or interconnectedness between forms of media in order to enhance communication. As it participated in these conventions of modern periodicals, the distinguishing factor of The Woman's Era was that it was by, about, and for black women, which we can recognize in one of its profile editorials.

The May 1894 edition of The Woman's Era announces its complex focus on black women with an editorial profile on the first page praising the work of leading clubwoman, Victoria Earle Matthews. ${ }^{42}$ Under a neat Victorian style portrait of Matthews, looking off camera with a self-assured steady gaze, the profile proclaims: "We read daily of the progres[s] women are making for the elevation of their sex and we are [proud] to note noble examples among us, who follow in their train, laboring earnestly yet modestly for their sex and the building up of their race. Surely we cannot know too much of their genius and merits, for the inspiration of our girls." 43 The fact that black clubwomen "cannot know too much" about themselves displaces any previous absence of social data with a productive curiosity for younger generations, and, as Ruffin later notes, knowing about women like Matthews is also essential "for the success of the futurity of the race." 44 This curiosity is further configured by a collective recognition shared between black women in the positions of editor, reformer, reader, and subject. Ruffin continues to present Matthews's accomplishments as the head of a local women's club, a short story writer, and a social reformer.

Victoria Earle Matthews is known for her work as a clubwoman and director of the White Rose Mission in New York, a settlement house that particularly sought to help young black girls who came to the city in search of jobs, independence, and to escape the increasing violence in the Jim Crow South. She was a prolific short story writer in the late nineteenth century, often performing what literary scholar Elizabeth McHenry calls a "literary activism," depicting and protesting the realities of black life during the period. ${ }^{45}$ Scholars have accorded less attention to her efforts to conduct social surveys as part of her reform work. Ruffin, however, readily weaves Matthews's accomplishments together in the bulk of the profile:

Among our prominent progressive women is Mrs. William E. Matthews, known in the literary world as "Victoria Earle." 
Mrs. Matthews, so desirous of doing what she can for her race, with few others saw the practical need of banding together well-thinking women with the hope that they might in their generation pave the way for the success of the futurity of the race, and organized The Woman's Loyal Union. We are favored to exist in the seed planting time [...] Realizing the wrongs perpetrated upon our race in the South, the injury occasioned by opinions that have been freely expressed in several leading magazines and newspapers, [such as] the retrogression of the race morally. Mrs. Matthews has been exceedingly anxious to ascertain the truth of such statements.

With this idea in view she wrote a set of questions, submitted them to the executive board of the Union with the hope of their approval, and expressed the desire to have questions sent to ministers, school teachers, and other representative men and women throughout the country for the purpose of eliciting from them the true statistics of our people morally. The idea is bright, progressive. ${ }^{46}$

Here again the broader archive of black clubwomen's writing within the Progressive Era proves key for appreciating the set of sociologically-informed aesthetics employed in the profile. The act of soliciting and ostensibly obtaining social data based on survey material from figures within the black community performs a refutation of black pathology, particularly the notion that blacks were hypersexualized or criminal, which was often implied by accusations of being "immoral." The promise of social data transforms the accusation into a depiction of black social life as "tru[e,]" "mora[1,]" "bright," and "progressive." There is also a shared pleasure where Matthews's authority is validated and readers can look forward to knowing more about themselves from one of their own, even though the actual data is not published here. Ultimately the expression of the aesthetic involves the transformation of foreclosures of pathology into sociological possibility and the production of affective collective affirmation. The change in social narrative, the characterization of a modern insightful progressive black woman - this is the vision, the art, the pleasure that black clubwomen offer one another in the periodical. Indeed, it is a beautiful thing when a literary act can both challenge the epistemological violence of anti-blackness and make black women feel good about themselves and one another. ${ }^{47}$

Matthews's survey is also an example of how black clubwomen contribute to the early history of sociology. As Francille Rusan Wilson has observed, based on the apparent design of the study and its intent (as mentioned in the editorial), we can readily regard Matthews's initiative as a distinct "modernist response to social planning." 48 Matthews started such work using The Woman's Era as a means of gathering and circulating data and continued her research as a director of the White Rose Mission. For these reasons, Wilson suggests that Matthews, 
along with other clubwomen including Fannie Barrier Williams and Mary Church Terrell, warrant greater recognition as early founders of black sociological study, especially given that their efforts occurred in the early 1890s before W.E.B. Du Bois began his study of Philadelphia or Atlanta. ${ }^{49}$

\title{
The Dream and Experiment Aesthetics of Experience in The Woman's Era
}

A year after Ruffin's editorial profile on Victoria Earle Matthews, the May 1895 issue of The Woman's Era featured an imaginative sketch by a clubwoman entitled "An Experiment with a Kinetoscope and a Phonograph." It offers another example of black clubwomen's aesthetic expression incorporating their experience and outlook on racial progress and reform within the imaginative register of the sketch. Sketches, segments of dialogue or scenes preliminary in nature, render a single scene, character, or incident. They are comparable to their visual namesakes in chalk or charcoal, which precede a full painting. ${ }^{50}$ The sketches in The Woman's Era often lack the context or framing necessary for the reader to decide if the writing is fiction, a reflection, or an account of an actual event. Their form in the intermedial context of a periodical blurs the lines between artistic creation and biography or autobiography in order to aestheticize dayto-day experience. Such is the case with "An Experiment with a Kinetoscope and a Phonograph." Over the course of the sketch, a third-person narrator tells of a black bourgeois man returning to his home with technology that allows his wife, referred to by her pet name "Cherie," to see and hear happenings in the city. The wife sees different scenes of city life that connect to social issues in black America during the period. The husband offers his thoughts on the issues. Then the third-person narrative voice is interrupted with a dash and switch to the perspective of the wife, now referred to by her actual name, "Petite," realizing she dreamed of the experiment. The sketch ends with another simple dash and the revelation of the author's full name, Petite Reine. The plot, perspectives, and narrative layers in the sketch are key to its aesthetic effects. The sketch opens with what initially seems like a simple scene of black bourgeois life as follows:

\begin{abstract}
A man and a woman in a plainly furnished room. He says, Cherie, knowing how lonely your life is, I bought and arranged this kinetoscope with views of the happenings of today among our people in Gotham, also a phonograph, so that you may know the talk of the day. If you will place yourself at the kinetoscope, I will shift the scenes and explain, according to my ideas. ${ }^{51}$
\end{abstract}

The marvel of the technology of the kinetoscope and the phonograph as signifiers of modernity, material wealth, and economic stability would have readily drawn the appreciation of black middle-class women readers. The kinetoscope was first introduced at the Chicago Exposition in 1893. It was a large box with 
an opening through which a single viewer could peer inside and see films up to 90 seconds long. The length of the sketch, roughly a few paragraphs, reflects the brevity of the moving picture. The passive wife, "Cherie," sees much of her changing world, including prominent black women signing a petition to have black teachers in "mixed schools" (integrated schools), a large crowd of unemployed black people loitering in the street because "colored people as servants have gone out of style," and a group of middle-class black men and women paying the white owner of a dance hall for admission although they should "cooperate and have buildings of their own." 52 Through the kinetoscope and phonograph the experience becomes virtual, something in between empiricism and idealism and produced by technology. There is the potential for prejudicial standards to shift, unemployment issues to be addressed, and black business to emerge, even as these social conditions indicate the various obstacles black Americans faced. ${ }^{53}$ The idea of the virtual I employ here, in deference to Katherine Biers in her work, Virtual Modernism: Writing and Technology in the Progressive Era, is predicated on the idea of the virtual as a matter of the potential of experience as opposed to being "fake" or unreal. ${ }^{54}$ The potential of the virtual also includes what might come into existence or might be, especially if the self extends beyond a position or constraint. And Cherie is constrained by the social expectations of her patriarchal household. Cherie offers some comments as she watches and listens, yet she and her husband are largely in agreement about social conditions and potential resolutions, and his ownership of the technology makes his mediation far more authoritative. The virtual experience seems to be defined by a patriarchal dynamic until the end of the sketch when it is revealed that the experiment is a dream conjured by the author herself. In the last lines of the sketch, before there can be another picture or sound for Cherie and her husband to explore, a series of voices disrupts and ends the sketch: "Petite, do you mean to sleep all day? Asleep! Is it possible? And it was only a dream after all!" "P5 "Petite" is awoken by the voice of her husband, then muses to herself through free indirect discourse that it all was a dream. Cherie, the woman in the experiment, then, is not necessarily following the lead of her husband, but the unconscious thought of another version of herself, Petite. The metaphysical narrative then yields to a third figure of consciousness when the author's full name, Petite Reine, is disclosed at the end of the sketch.

"Cherie," "Petite," and "Petite Reine" offer three levels of experience and narrative mediation crafted to validate a black woman's social thought about the "Negro problem," while acknowledging the constraints she must operate within. Cherie is a passive figure because she sees the world through technology bought by her husband. Petite awakens from the dream indicating an unconscious desire to know the social world and comment on it. And Petite Reine, the author, creates these dual versions of herself that illustrate the patriarchal binds black women face and their potential to theorize the world. Reine's sketch rhetorically appeals to technology, and even patriarchy, in order to make provocative sociological observations about the systematic nature of Jim Crow in a Northern city (i.e. 
"Gotham," or New York City). Her writing innovates technology responsible for creating a virtual experience so she can cleave the authority of empiricism from the patriarchal figure of her husband, without challenging the status quo. ${ }^{56}$ Her aesthetics here are as much an experiment as the use of the kinetoscope and phonograph, ultimately producing a narrative experience that might be comparable to the sensory data of experience.

For these reasons, we can think of her experiment as an example of what Biers calls "virtual poetics," or the writing that emerges out of the modern drive to use language to "find a common ground in a world governed by media other than print," including mass print culture like newspapers and the sensory experience produced by machines. ${ }^{57}$ Such is the case here when Petite Reine's framing of technology within a dream necessarily reimagines the dream to a greater potential to express experience in its totality. According to Biers, virtual poetics also allow "[aspects] of experience that had been narrowly defined as outside the purview of reason-including introspection, emotion, dreams, and other suspensions of conscious perception - [to be] reimagined much more expansively in the late nineteenth century," making different forms of experience gain greater potential as a reflection of reality. ${ }^{58}$ Even though every level of the sketch is Petite Reine's imaginative construction, her social thought and articulation of the challenges within black social life are real.

Petite Reine's literary experiment fits into a larger trend of black girls and women performing experiments through their praxis of living and imagining of black life, particularly as theorized by black studies and literary scholar Saidiya Hartman. In her recent groundbreaking text, Wayward Lives, Beautiful Experiments: Intimate Histories of Riotous Black Girls, Troublesome Women, and Queer Radicals, Hartman insists upon seeing the lives of black girls and women at the turn of the twentieth century as more than a series of social problems. Through her careful examination and presentation of their living as a series of social “experiments," Hartman (much like Brittney Cooper) postulates through her own archival trust in black girls of the city that "Experiment was everywhere. It was a ubiquitous term employed to describe a range of social projects - from the settlement house to a laboratory of sociology to a model tenement, from aesthetic and scientific innovations to radical designs for living. It was a term bandied about. There was nothing precious or unusual about seeking, venturing, testing, trying, speculating, discovering, exploring new avenues, breaking with traditions, defying the law, and making it, except that hardly anyone imagined that young black women might be involved in this project too." 59 The experiments black women conduct through the praxis of their experience enables them to create their own intimate worlds, social thought, and visions of freedom. Reine uses the imaginative capacities of the sketch within the space of the periodical to effectively play with the processes by which experience can become social fact. ${ }^{60}$ Hers is an experiment that features a mediated radicalism, incorporating the patriarchal bourgeois constraint to which middle-class black women were necessarily disposed. Nevertheless, her transformation of experience is an ex- 
periment that allows her to wield the technology of modern entertainment and access the virtual, while still upholding the value of black female subjectivity, whether it be in the home, through the machine, or on the page.

The aesthetic expression in "An Experiment with a Kinetoscope and a Phonograph," along with the editorial, involves black clubwomen asserting the inherent sociological merit in their own thought and experience, not unlike W. E. B. Du Bois's formation of double consciousness in The Souls of Black Folk (1903). ${ }^{61}$ Within black studies and literary studies, Du Bois is the foremost figure scholars think of as engaging discourses of sociology within literary production, particularly in The Souls of Black Folk. Du Bois's sociological thought transformed within a new realm of expression in this genre-bending compilation, which features a combination of sociological and historical analysis, personal essay, fiction, and song. While the "Negro problem" continued to exist for him as a sociological concern, the introduction of more aesthetic and narrative forms, especially the personal essay, allowed Du Bois to assess the problem within a different register, yielding to a number of intellectual productions, most notably double consciousness. Within the concept of double consciousness, the black subject regards himself as being black and yet "American," as Du Bois puts it. Much like that of black clubwomen, his formulation of double consciousness depends on both dispossession and the prospect of citizenship. It is also an ontology of blackness that Du Bois accesses as a sociologist and black subject when he poses the question, "How does it feel to be a problem?":

Between me and the other world there is ever an unasked question: unasked by some through feelings of delicacy; by others through the difficulty of rightly framing it. All, nevertheless, flutter round it. They approach me in a half-hesitant sort of way, eye me curiously or compassionately, and then, instead of saying directly, How does it feel to be a problem? they say, I know an excellent colored man in my town; or, I fought at Mechanicsville; or, Do not these Southern outrages make your blood boil? At these I smile, or am interested, or reduce the boiling to a simmer, as the occasion may require. To the real question, How does it feel to be a problem? I answer seldom a word. ${ }^{62}$

In his social history of the black race offered in brief, from a Civil War battle at Mechanicsville to the contemporary issue of "Southern outrages" or antiblack violence, the "Negro problem" persists over time. The subjectivity afforded by the personal essay then allows the objectivity implied by "a problem," the emergent allusion to black pathology within sociology, to become malleable, murky, and even yielding to alternative possibilities. In addition to the status of being a problem, there is also a feeling that escapes and exceeds the problem in ways that Du Bois continues to depict and contemplate in the rest of The Souls of Black 
Folk. From feeling, Du Bois expands across his compilation to configure and contemplate the irreducible aspects of black being that emerge out of and defy the ontology of being a problem. As my reading of Du Bois suggests, black clubwomen have a parallel yet distinct approach to sociology and literary production. Black clubwomen then are not simply Du Bois's contemporaries - they are his interlocutors. As Du Bois affectively ponders the ontology of being a problem, black clubwomen imagine art in spite of their dispossession; where Du Bois locates a division of self through double consciousness, Petite Reine performs a series of deferrals creating a multiplicity of self. The archives of Du Bois and clubwomen are in conversation - and this fact critically maps and expands the terrain of black intellectual thought and aesthetics in this moment.

\section{Conclusion}

At the turn of the twentieth century, black clubwomen faced the epistemological feat of trying to convince American society that black women were ideal citizens and representative of the broader social progress of the race. Because of their subject position as black women in the context of the Progressive Era, they were necessarily excluded from the sociological discourses of authority and cultural influence in which they aimed to intervene. With little to no access to formal academic institutions or resources, they continued to perform their reform work with a basis in empirical scientific methods and in their writing they sought to marshal the ideological influence of social data by refashioning it through rhetorical and literary means. Reading black clubwomen's intellectual thought and aesthetics within the archive of their writing asks us to reckon with what it really means to desire social data about black life- - how soliciting it, searching for it, and even dreaming of it, can set the stage for black intellectual sovereignty and literary acts capable of substantiating the black experience as art and social fact.

\section{Notes}

1. Mary Church Terrell, "What Role is the Educated Negro Woman to Play in the Uplifting of Her Race," Quest for Equality: The Life and Writings of Mary Eliza Church Terrell 1863-1954, Beverly Washington Jones, ed. (Brooklyn, NY: Carlson Publishing Inc., 1990), 156.

2. Mary Church Terrell, "The Progress of Colored Women," in Quest for Equality, 183-87.

3. Gerda Lerner, "Early Community Work of Black Club Women," Journal of Negro History 59, no. 2 (April 1974): 159; Deborah Gray White, Too Heavy a Load: Black Women in Defense of Themselves, 1894-1994 (New York: W. W. Norton, 1999).

4. The black clubwomen's movement was distinct from the club movement organized by white women. Even though both groups were invested in expanding the social and political agency of women in the context of modernity, white clubwomen largely excluded black women from their organizations and black clubwomen were specifically invested in the uplift of the race as the passages presented at the beginning of the piece suggest.

5. Barbara Harris explores how in the nineteenth century, the culture of true womanhood or domesticity, a cultural ideology defining the roles and capacities of men and women especially in the Victorian period, was based on a series of binaries that emphasized the intellectual inferiority of women. As Harris explains, "Household work and child rearing remained, as they always had been, the heart of married women's work, but now these functions were given a new ethical and spiritual significance. This vision of women's social mission was dependent on a complex view of femininity that associated it with nature, the emotions, and the soul and saw it as completely opposed to 
intellect and reason" (40). Barbara J. Harris, Beyond her Sphere: Women and the Professions in American History (Westport, CT: Greenwood Press, 1978).

6. White, Too Heavy a Load, 115-16; Hazel Carby, Reconstructing Womanhood: The Emergence of the Afro-American Woman Novelist (New York: Oxford University Press, 1988).

7. See particularly, Hazel Carby, "Policing the Black Woman's Body in an Urban Context," Critical Inquiry 18, no. 4 (Summer 1992): 738-55.

8. Carby, Reconstructing Womanhood. The phrase "the Woman's Era" is also used to name the more general, yet predominantly white movement of women out of the domestic sphere, but I am mobilizing the phrase as it was used by black authors and intellectuals during the time period under discussion and in black studies today.

9. Elizabeth McHenry, Forgotten Readers: Recovering the Lost History of African American Literary Societies (Durham, NC: Duke University Press, 2002).

10. Hazel Carby, Joy James, and Brittney Cooper offer a critique of scholarly focus on black male intellectuals typically at the expense of black women. Moreover, the politics of archival work and analysis always lean toward a single narrative as opposed to a collective, in this case a renowned race man as opposed to a group of women. Hazel Carby, Race Men (Cambridge, MA: Harvard University Press, 1998); Joy James, "Profeminism and Gender Elites: W.E.B. Du Bois, Anna Julia Cooper, and Ida B. Wells-Barnett," in Next to the Color Line: Gender, Sexuality, and W.E.B. Du Bois, ed. Susan Gillman and Alys Eve Weinbaum (Minneapolis: University of Minnesota Press, 2007), 65-95; Brittney Cooper, Beyond Respectability: The Intellectual Thought of Race Women (Urbana: University of Illinois Press, 2017).

11. Cooper, Beyond Respectability, 4.

12. David Southern, The Progressive Era and Race: Reaction and Reform, 1900-1917; Thomas C. Leonard, Illiberal Reformers: Race, Eugenics, and American Economics in the Progressive Era (Princeton, NJ: Princeton University Press, 2016); Oz Frankel, States of Inquiry: Social Investigations in Print Culture in Nineteenth Century Britain and the United States (Baltimore, MD: John Hopkins University Press, 2008).

13. Ibid.

14. Craig Calhoun, "Sociology in America: An Introduction," in Sociology in America: A History, ed. Craig Calhoun (Chicago: University of Chicago Press, 2008), 3. For a specific historical account of race in sociology from its beginnings to the contemporary moment, see Howard Winant, "The Dark Side of the Force: One Hundred Years of the Sociology of Race," in Sociology in America: A History, ed. Craig Calhoun (Chicago: University of Chicago Press, 2008), 535-71.

15. Oz Frankel explains that "the culture of social fact" or increased interest in gathering social data, first by reformers and later by the state itself, was all part of a larger trend in print culture geared towards gathering social information in order to form institutions and rectify the nation fragmented and recovering from sectional divides resulting from the Civil War. Oz Frankel, States of Inquiry.

16. Eleanor Tayleur, "Social and Moral Decadence," Outlook 76 (January 30, 1904): 266-

17. At the request of organizers in Chicago, Terrell chose not to invite outspoken anti-accommodationist Ida B. Wells-Barnett to the first NACW meeting. Stephanie Shaw, "Black Club Women and the Creation of the National Association of Colored Women," Journal of Women's History 3, no. 2 (Fall 1991): 11-25.

18. Ida B. Wells, Southern Horrors and Other Writings: The Anti-Lynching Campaign of Ida B. Wells, 1892-1900, ed. Jacqueline Jones Royster (Boston: Bedford Books, 1997).

19. My reading of Wells's refashioning of statistics is inspired by Katherine McKittrick's call to "ethically engage with mathematical and numerical certainties that compile, affirm, and honor bits and pieces of black death." Katherine McKittrick, "Mathematics Black Life," The Black Scholar: States of Black Studies 44, no. 2 (2014): 18.

20. Frederick L. Hoffman, Race Traits and Tendencies of the American Negro, Publications of the American Economic Association, vol. 11, nos. 1-3 (New York: Macmillan Company, 1896).

21. Hoffman, Race Traits and Tendencies of the American Negro, 37.

22. Kelly Miller, A Review of Hoffman's Race Traits and Tendencies of the American Negro (Washington, D.C.: American Negro Academy, 1897).

23. W.E.B. Du Bois, review of Race Traits and Tendencies of the American Negro, by Frederick L. Hoffman, Annals of the American Academy of Political and Social Science 9, no. 1 (January 1897): $127-33$.

24. Ibid, 128 .

25. It is critical to note that the bastion of prejudice such white social scientists maintained impoverished the intellectual thought and praxis of early sociology. Social theorist and sociology historians like James McKee in Sociology and The Race Problem: The Failure of a Perspective (Urbana: University of Illinois Press, 1993) and more recently Aldon Morris in The Scholar Denied: W.E.B. Du Bois and the Birth of Modern Sociology (Berkeley: University of California Press, 2015 ), argue, respectively, that because there was a hegemonic white consensus that the black race was inferior culturally and biologically, late nineteenth and early twentieth century white social 
scientists struggled to recognize black social life and the contributions of black intellectuals. Morris particularly illustrates how racism undergirds and limits empirical sociology as he advances W.E.B. Du Bois as the father of empirical sociology: "White social scientists could not embrace black excellence in science, let alone the superiority of a black scientist . . . Thus they suppressed Du Bois's scholarship because it concluded that there were no scientific grounds on which to justify racial oppression and because they could not view Du Bois as an exemplary scholar who pioneered scientific sociology." Morris, The Scholar Denied, 4. Morris further explains that Du Bois's insistence that race was socially constructed and that study of social conditions made his thought and methodologies a more exact production of empirical science. Within Morris's explanation about Du Bois's more exacting sociology, there is a warrant, a kind of faith even, about the potential of social study to address and even resolve the myriad challenges black America faced. This belief in the social study as a means of restitution and resolution apparent in Du Bois's work is equally pronounced in the reform work and corresponding writing of black clubwomen.

26. Francille Rusan Wilson, The Segregated Scholars: Black Social Scientists and the Creation of Black Labor Studies, 1890-1950 (Charlottesville: University of Virginia Press. 2006); Mary Jo Deegan, "An American Dream: The Historical Connections Between Women, Humanism, and Sociology, 1890-1920," Humanity and Society 27, no. 3 (August 2003): 378-89; Patricia Madoo Lengermann and Jill Niebrugge-Brantley, The Women Founders: Sociology and Social Theory 1830-1930 (Boston: McGraw-Hill, 1998).

27. Francille Rusan Wilson offers one of the most comprehensive archival reviews of sociological research conducted by black clubwomen amongst other black social scientists in the nineteenth and twentieth centuries. In her work, she explains how black clubwomen did independent research that they often contributed to institutions of racial uplift and the study of black life including the Atlanta conferences, National Urban League, YMCA, and in the early twentieth century, the NAACP. These larger institutions of study and reform provided the infrastructure and resources for black women to gather and share their work, but the relative acknowledgment of black women's contributions was often absorbed by the institutions themselves, leaving the archival record of their work limited if not completely obscured. Wilson's assemblage of their work and club meeting notes about surveys suggest local gathering of data and use of more publically available social studies and statistics. Still, as I argue, the broader cultivation and circulation of social data about black women beyond accounts of black women that reproduced assumptions of their sexual and domestic frailty (e.g. in white society in academia or the press) remained limited at best. Wilson, The Segregated Scholars, 93-96. Mary Jo Deegan, Jane Addams and the Men of the Chicago School, 1892-1918 (New Brunswick, NJ: Transaction Publishers, 1990).

28. Mary Jo Deegan, "Fannie Barrier Williams and Her Life as a New Woman of Color in Chicago, 1893-1918," in The New Woman of Color: The Collected Writings of Fannie Barrier Williams, 1893-1918, ed. Mary Jo Deegan (DeKalb: Northern Illinois University Press, 2002), xxix.

29. Lee D. Baker, From Savage to Negro: Anthropology and the Construction of Race, 1896-1954 (Berkeley: University of California Press, 1998), 56.

30. Deegan, "Fannie Barrier Williams and Her Life as a New Woman of Color in Chicago, 1893-1918," xxix.

31. Fannie Barrier Williams, "The Intellectual Progress of the Colored Women of the United States Since the Emancipation Proclamation," in The New Woman of Color: The Collected Writings of Fannie Barrier Williams, 1893-1918, ed. Mary Jo Deegan (DeKalb: Northern Illinois University Press, 2002), 18.

32. To conserve space, I am focusing exclusively on Fannie Barrier Williams's theory of black aesthetics. That said, as scholars have noted, black clubwomen and intellectuals Anna Julia Cooper and Victoria Earle Matthews also offer aesthetic theories about the next generation of "race literature." In their respective works, they too envision literary production as a means of asserting national recognition for the race and suggest that the social history of the Negro has the capacity to inspire modern artistic tradition. In her essay "One Phase of American Literature" (1892), Anna Julia Cooper connects literature to a sense of nation and a sense of self, both of which are of particular importance to the black race. Victoria Earle Matthews opens "The Value of Race Literature" (1895) with a definition of literature as "embracing the entire results of knowledge and fancy, preserved in writing," a composite she associates with social science as much as scripture. Matthews's definition of the literary relies on the new epistemologies and tradition. She also compares America's rise to nationhood to the emergence of race literature and proposes that the particular purpose of race literature is to reveal the Negro as an "American race of the future." Victoria Earle Matthews, "The Value of Race Literature: An Address Delivered at the First Congress of Colored Women of the United States, at Boston, Mass., July 30 $30^{\text {th }}$, 1895," in The New Negro: Essays on Race, Representation, and African American Culture, 1892-1938, eds. Henry Louis Gates and Gene Andrew Jarrett (Princeton, NJ: Princeton University Press, 2007), 288. Anna Julia Cooper, "One Phase of American Literature" in The New Negro: Essays, 157.

33. Williams, "The Intellectual Progress of the Colored Women of the United States," 18.

34. Williams, "The Intellectual Progress of the Colored Women of the United States," 20. 


\section{Erica Richardson}

35. Frances Harper wrote four novels between 1868 and 1892, including her most famous piece, Iola Leroy (1892). Pauline Hopkins wrote five novels between 1900 and 1916, as well as a number of plays. Her most recognized text is her first novel, Contending Forces (1900).

36. Williams, "The Intellectual Progress of the Colored Women of the United States," 20.

37. "Only the BLACK WOMAN can say "when and where I enter, in the quiet, undisputed dignity of my womanhood, without violence and without suing or special patronage, then and there the whole Negro race enters with me." Anna J. Cooper, A Voice from the South (Xenia, OH: The Aldine Printing House, 1892), 31.

38. White, Too Heavy a Load; Shaw, "Black Club Women and the Creation of the National Association of Colored Women."

39. Ann Ardis, "Staging the Public Sphere: Magazine Dialogism and the Prosthetics of Authorship at the Turn of the Century," in Transatlantic Print Culture, 1880-1940: Emerging Media, Emerging Modernisms, eds. Ann Ardis and Patrick Collier (New York: MacMillan, 2008).

40. Baker, From Savage to Negro, 1998.

41. Ardis, Ann. "Staging the Public Sphere," 30.

42. [Josephine Ruffin], "Mrs. W.M E. Matthews (Victoria Earle)," The Woman's Era 1, no. 2 (May 1894): 1.

43. "Mrs. W.M E. Matthews (Victoria Earle)."

44. "Mrs. W.M E. Matthews (Victoria Earle)."

45. McHenry, Forgotten Readers, 190.

46. "Mrs. W.M E. Matthews (Victoria Earle)."

47. Related to my argument about black women producing a distinct social data inspired aesthetic in The Woman's Era, is Elizabeth McHenry's work discussing the implications of black clubwomen in reading societies. McHenry argues that by reading together black clubwomen formed a new standard of what literature could and should be through their approach to reading and selection of authors, which often contradicted traditional literary standards. She also uses The Woman's Era as a resource for exploring how black clubwomen valued literature and performed their own distinct reading practices. McHenry, Forgotten Readers.

48. Wilson, The Segregated Scholars, 93.

49. Ibid., 102-3.

50. Ned Stuckey-French offers this useful definition of a sketch as part of the essay. See Stuckey-French, The American Essay in the American Century (Columbia: University of Missouri Press, 2011).

51. Petite Reine, “An Experiment with a Kinetoscope and a Phonograph,” The Woman's Era 2, no. 2 (May 1895): 3.

52. Reine, "Experiment with a Kinetoscope," 3.

53. The idea of the virtual I am using here is theorized by Katherine Biers in her work Virtual Modernism: Writing and Technology in the Progressive Era (Minneapolis: University of Minnesota Press, 2013). Biers builds on an idea of the virtual that emerges out of the philosophy of Aristotle then connects that to the vitalist movement in nineteenth-century America as formulated by Henry Bergson and William James. All of these figures think of the virtual as a matter of the potential of experience as opposed to being "fake" or unreal. The virtual as potential considers what might come into existence or might be, especially when the self extends beyond a position or constraint.

54. Biers, Virtual Modernism, 2.

55. Reine, "Experiment with a Kinetoscope," 3.

56. Here I explicitly claim that the writing "innovates" the technology to gesture to a reversal of the hierarchy of technology over language and writing. Writing and language can and do affect the cultural meaning and influence of technology. At the onset of modernity, especially in America, there was an assumption that technology and new forms of mass media would surpass language and the more traditional literary modes, but as my reading suggests, that was not always the case. I maintain this perspective with deference to Katherine Biers's aforementioned work.

57. Biers, Virtual Modernism.

58. Ibid., 11.

59. Saidiya V. Hartman, Wayward Lives, Beautiful Experiments: Intimate Histories of Riotous Black Girls, Troublesome Women, and Queer Radicals (New York: W. W. Norton, 2019), 60.

60. It is important to note that while I use Hartman's formulation of experiment as a way of reading the archive of clubwomen, they were often the figures of authority that regulated the black girls that Hartman focuses on in her work. Hartman also questions the legitimacy of sociology as a representation of black social life in productive ways which differs from my argument about the way black clubwomen perceive the potential of sociology as a part of their reform work and cultivation of their social thought. In this respect, the social politics of our respective subjects (working-class black girls versus middle-class clubwomen) and their relationship to sociology overlap but are not the same.

61. W. E. B. Du Bois, The Souls of Black Folk: Authoritative Text, Contexts, Criticism (New York: W. W. Norton, 1999).

62. Du Bois, The Souls of Black Folk, 9. 